Vol. 2 No. 3- December 2021

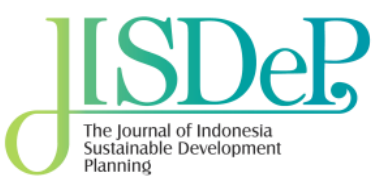

E-ISSN: $\underline{2722-0842}$ | P-ISSN: $\underline{2721-8309}$

Available online at

Kementerian PPN/ Planning

\title{
Youth Awareness Level towards Sustainable Development Goals (SDGs) in Greater Kuala Lumpur
}

\author{
Zul Ilham ${ }^{1,2 *}$, A'syara Kamal ${ }^{1}$, Wan Abd Al Qadr Imad Wan-Mohtar ${ }^{1,2}$ and \\ Adi Ainurzaman Jamaludin ${ }^{1,2}$
}

Environmental Science and Management, Institute of Biological Sciences, Faculty of Science, Universiti Malaya, Kuala Lumpur, Malaysia ${ }^{1}$

Bioresources and Bioprocessing Research Group, Institute of Biological Sciences, Faculty of Science, Universiti Malaya, Kuala Lumpur, Malaysia²

Email:1ilham@um.edu.my, ${ }^{2}$ syarakamal@gmail.com, ${ }^{3}$ qadyr@um.edu.my, ${ }^{4}$ adiainurzaman@um.edu.my

*Corresponding Author

\section{ABSTRACT}

In 2015, the United Nations initiated the Sustainable development goals (SDGs) to address the global changes while ensuring better and sustainable actions for the future. Among Asian countries, Malaysia has also made an effort to integrate the SDGs into its national development plan. In this study, the awareness level of youth from high schools in Greater Kuala Lumpur towards Sustainable Development Goals has been assessed through questionnaires with 60 questions given to 421 respondents. Sufficient levels of feedbacks for the whole population were acquired (Confidence level: 95\%, Margin of error: 5\%). Five schools were selected and grouped into 3 types: high performance school (national merit of excellence), cluster school (state level merit of excellence), and daily school (normal achievement). The results of the Spearman Rho correlation showed a significant but weak relationship $[r=0.435]$ between attitude and practice for all schools. Interestingly, the statistical test showed a negligible relationship between knowledge and attitude, and knowledge and practice, indicating a low attitude to practice SDGs amongst youth although equipped with adequate knowledge. The study also found that high performance schools showed the highest score for all knowledge, attitude, and practice.

Keywords: sustainable development goals, environmental sustainability, youth, Asian, awareness

\section{ARTICLE INFO}

Received: August 14,2021

Received in revised form: October 15 , 2021

Accepted: December 4, 2021
JISDeP - The Journal of Indonesia Sustainable Development Planning Published by Centre for Planners' Development, Education, and Training (Pusbindiklatren),

Ministry of National Development Planning/ National Development Planning Agency (Bappenas), Republic of Indonesia
Address: Jalan Proklamasi 70,

Central Jakarta, Indonesia 10320

Phone: +62 $2131928280 / 31928285$

Fax: +62 2131928281

E-mail:

journal.pusbindiklatren@bappenas.go.id

Supported by Indonesian Development Planners

Association (PPPI) 


\section{Introduction}

Sustainable development definition is the effort to meet current needs without affecting future generations' ability to do the same (Ideland and Malmberg, 2014). As our environment is rapidly deteriorating, we need to adjust our lifestyle and everyday routines to rectify this issue collectively. This is very much aligned with the initiative by the United Nations; the Sustainable Development Goals (SDGs).

Before SDGs were initiated, the Millennium Development Goals (MDGs) kicked off the attempt to improve our world. From 2000 through 2015, the Millennium Development Goals (MDGs) aided in producing evidence to track and monitor poverty. Achieving the MDGs indicates success in taking measures to eradicate poverty and environmental damage (Sachs, 2012). Some emerging nations accomplished their 8 objectives of MDGs and even improved. As a consequence, the MDGs have inspired nations across the globe to develop and provide better planning for the future generation (Carant, 2017).

Due to the fact that most countries want recognition in the area of environmental, economic, and social aspects, SDGs have become a focal point (Sachs, 2012). There is an urgent need for increased visibility and change in the process of developing global goals for the majority of countries, as they are all confronted with environmental and socioeconomic concerns. In general, the economy is highly dependent on the environment, to the point that environmental difficulties can lead a country to lose revenue from investment, hence lowering the standard of living for its population (Kristensen and Mosgaard, 2020).

Malaysia's population is expected to reach $80 \%$ urbanization by 2030 . The objectives of promoting green cities and providing high-quality services to residents should be achieved by then. Malaysia is projected to catch up and boost the economy through improved communication and high-end technologies (Hamid, 2013). Efforts to link the 11th Malaysia Plan with the Sustainable Development Goals were made to ensure that Malaysia is capable of achieving those goals by 2030 (Nazry, 2021).

Malaysia ranked 55th out of 156 countries in the SDG index report 2018, scoring 70 (Hamid, 2013). The SDGs are more specific than the Millennium Development Goals, with 17 goals and 169 indicators for each goal. In 2016, the government and commercial sector collaborated to connect the SDGs with the 11th Malaysia Plan. Promisingly, Malaysia has made positive progress on eight of the Sustainable Development Goals (SDG1: Poverty reduction, SDG2: Ample food supply, SDG3: Health and sanitation, SDG5: Gender balance, SDG9: Resilient infrastructure, SDG14: Marine conservation, SDG15: Life on land, SDG17: Global partnership). According to Malaysia's Voluntary National Review of the Sustainable Development Goals for 2017, the country has achieved considerable strides in economic development, particularly in rural regions, alleviating poverty (Ang, 2021).

Malaysia is firmly committed to the Sustainable Development Goals objectives and our 2030 global transformation goals, as evidenced by related policy and planning. As a result, the Economic Planning Unit produced the Sustainable Development Goals Roadmap for Malaysia in order to incorporate the 2030 Agenda into the Eleventh Malaysia Plan (Lee \& Chew-Ging, 2017). The 11th Malaysia Plan's theme, "Anchoring growth on people," fits well with the SDG concept of "leaving no one behind." Three objectives have been established under the theme; people are the nation's bedrock, people are prepared for the future, and everyone benefits from growth and development.

Malaysia's SDG roadmap was then categorized into three phases which are (Nazry, 2021):

- Phase 1 (2016-2020) - Prioritizing SDG according to $11 \mathrm{MP}$

- Phase 2 (2020-2025) - Focus on post-2020 goals and targets

- Phase 3 (2025-2030) - Pursuing targets in line with Malaysia's capability and capacity

Therefore, aligned with the current roadmap to achieve the targets by 2030, it is interesting to evaluate the awareness towards SDGs amongst the youth in Greater Kuala Lumpur, which is a term that determines the geographical boundaries of Metropolitan Kuala Lumpur, covering 2793 square kilometers (Yap et al., 2021). The main purpose of this study is to evaluate the level of youth awareness regarding SDGs to benchmark the current condition and formulate policy planning to ensure that the action plan made could be directly strategized in realizing the Sustainable Development Goals Roadmap for Malaysia by 2030 . The strategies are oriented on students' knowledge, attitudes, and practices with the goal of instilling a sense of responsibility for environmental, economic, and social challenges. 


\subsection{Reflections on the Global Goals}

Previously, in 2000, the United Nations established The Millennium Development Goals (MDGs), a set of eight goals that focused on the public's attention worldwide. MDGs track each country's progress toward achieving them; some countries accomplish more, while others achieve less. Because it was not a legally binding agreement, it placed a greater emphasis on each country's capacity to accomplish those eight goals. They learned via the MDGs that participation from affluent nations is necessary to provide financing for those developing countries, as the MDGs are more focused on poverty alleviation. Additionally, the MDGs are being promoted to the general public, including non-governmental organizations and students at all levels (Sachs, 2012).

In 2012, the United Nations sought to continue the effort of encouraging countries to cooperate by establishing a new set of goals known as the Sustainable Development Goals (SDGs). All countries are encouraged to participate in these ultimate aims. Even while those wealthy and developed countries have a higher standard of living, they must be aware that certain individuals are being left behind. These global aims encompass the environment, the economy, and society. These factors are interconnected in order to attain a more favorable future in 2030. (Sachs, 2012). SDGs are being hailed as a transformational instrument capable of altering the course of human history. Sachs (2012) also stated that the SDGs will not be achieved by a top-down strategy but would require critical thinking and maximal collaboration from all organizations, including educational institutions and, of course, the young people who will need empowerment to survive the tough period.

Although the SDGs have been described as a transformational instrument capable of changing the world, there are also obstacles associated with its implementation, including data scarcity, target prioritization, and accountability. Each SDGs has its own metrics for tracking progress, which necessitated the collection of essential data. Unfortunately, the World Bank did not have poverty estimates for half of the 155 nations it watched and tracked (Afroz \& Ilham, 2020). Without full data, we are unable to evaluate progress and decide which policies work best. Working concurrently on 17 goals would be challenging, but determining which ones should be prioritized would be more difficult. However, each country must recognize that the objectives are inextricably linked. Concentrating greater focus on any one of the objectives that were the source of the issues may result in improvements to the other goals as well. For instance, reducing poverty may have a beneficial effect on one's health and well-being. Finally, the SDGs lack a structured accountability mechanism. In this instance, developing nations may benefit from the implementation of Public-Private Partnerships, as these organizations would be beneficial in managing public resources. By utilizing this method, the private sector will become more conscious of their activities and will begin to be more accountable for their acts, which will alleviate the load on government, particularly in terms of cost.

\subsection{Sustainable Development Goals and Education}

Education is the necessary approach for guiding our thinking and behaviour. It is also a means of disseminating knowledge via teaching and learning. To strike a balance between the desire for a better future and the need for education, Education for Sustainable Development (ESD) was created. ESD served as a vehicle for imparting and acquiring the necessary information to individuals of this age in order to meet new problems. Additionally, it develops a more responsible human being by increasing their awareness of their everyday activities and their influence on the social, cultural, economic, and environmental spheres.

Prior to 1992, ESD was recognized at the United Nations Conference on Environment and Development (UNCED) in Rio de Janeiro, the 2002 World Summit on Sustainable Development (WSSD) in Johannesburg, South Africa, and the 2012 United Nations Conference on Sustainable Development (UNCSD) in Rio De Janeiro, Brazil. Individuals also learn to solve problems through ESD by offering ideas through collaboration, inter- and transdisciplinarity, and formal and informal learning integration. The establishment of an ESD route would enable a varied collection of individuals to support sustainable development (Isa, 2017).

As Sachs (2012) noted, cooperation at all levels of the community is necessary to accomplish the SDGs. Exposure and education on global goals should be provided to young people in particular since they will become the experts and leaders of the future. As a result, their present degree of awareness and understanding regarding these 17 objectives should be determined. 
As the Sustainable Development Goals 2030 encompass the environment, social development, and economic development, each of these areas should be thoroughly explored and exposed to our children. On the environmental front, Aminrad et al. (2013) discussed how our kids lack environmental awareness, knowledge, and attitudes as a result of inadequate exposure in the curriculum. In general, they discovered that pupils had a considerably more favorable opinion of environmental concerns. They also compared their findings to those from other nations such as America and Singapore, demonstrating that Malaysians have a strong grasp of environmental concerns.

While in Malaysia, our study is more focused on environmental sensitivity. Hassan et al. (2010) performed a study on secondary school students to ascertain their level of environmental knowledge with regards to the idea of sustainable development. Although the students demonstrated a high level of environmental awareness, they were unable to connect it to other components of sustainable development. Their findings indicate that there is a very tenuous link between environmental awareness and sustainable measures. Their level of awareness makes little difference in terms of taking action to improve their surroundings. Additionally, research from Balikesir, Turkey, concluded that a high degree of environmental knowledge did not translate into active environmental involvement (Altin et al., 2014).

A comparison was made between students enrolled in the science stream and those enrolled in the arts stream, as well as between urban and suburban students. Students in the science stream demonstrated a greater level of environmental awareness than students in the art stream, owing to their exposure to some environmental themes during biology lessons. Additionally, urban students had a greater level of environmental awareness than suburban students, which might be explained by their socioeconomic status, affluence, and education (Hassan et al., 2010).

While in Balikesir, Turkey, another study was conducted on environmental consciousness, focusing on the link between money and awareness. The study discovered that the higher a family income, the higher its Environmental Awareness and Active Participation Scale score. Interestingly, they connect it to their mother's previous education, implying that their mother has a greater effect on their children's views and behaviors. Additionally, this study found that children from urban areas have a greater level of environmental awareness than students from suburban areas.

In 2014, research in Sweden examined the sustainability consciousness of upper secondary pupils. Numerous schools in Sweden include sustainable development into their curricula by establishing an environmental policy to mitigate adverse environmental impacts and educate pupils about human rights and gender equality (Berglund et al., 2014). They chose respondents from schools with a focus on sustainable development and schools without a focus on sustainable development in their profiles, as well as students from the two most prevalent majors, science and social science. They discovered substantial disparities in sustainability consciousness between students from environmentally sustainable development schools and pupils from traditional institutions.

According to Hassan et al. (2010), kids should have broad access to reading materials on sustainable problems since they may act as a conduit for knowledge to their family and community. Education curricular should be enhanced to include models of environmental attitudes and behaviors.

\subsection{Sustainable Development Goals and Youth}

According to the United Nations, there are 1.8 billion individuals between the ages of 10 and 24 years old (Borges et al., 2017). These individuals should be empowered for the greater good since they may act as agents of change to enhance human lives and the environment. Even the United Nations offered a venue for these young people to speak and discuss their thoughts about how to translate global aims into local ones. Additionally, the UN announced the 17 Young Leaders in September 2016 to urge them to get involved with the SDGs and to recruit additional young people to the cause. According to the United Nations, youth are critical thinkers, change agents, innovators, communicators, and leaders (Borges et al., 2017).

Through the SDGs, youth may get valuable experience and may develop into the 21st Century's future leaders (Borges et al., 2017). Pupils or kids who form their own groups are able to mobilize and enhance other students. It is similar to a ripple effect, which will result in more effort toward better serving the globe, beginning locally. 


\subsection{Malaysia and Sustainable Development Goals 2030}

Malaysia was placed 55th out of 156 nations in the SDG 2018 Index and dashboard report, earning a score of 70 for the SDG index (Hamid, 2013). The SDGs are more comprehensive than the Millennium Development Objectives, with 17 goals and 169 indicators for each target. In 2016, the government and corporate sectors collaborated to connect the SDGs with the 11th Malaysia Plan. Malaysia has achieved progress on eight of the Sustainable Development Goals, as previously highlighted at the 2017 High-Level Political Forum:

- Goal 1: End poverty in all its forms everywhere

- Goal 2: End hunger, achieve food security and improved nutrition, and promote sustainable agriculture

- Goal 3: Ensure healthy lives and promote well-being for all at all ages

- Goal 5: Achieve gender equality and empower all women and girls

- Goal 9: Build resilient infrastructure, promote inclusive and sustainable industrialization, and foster innovation

- Goal 14: Conserve and sustainably use the oceans, seas and marine resources for sustainable development

- Goal 15: Protect, restore and promote sustainable use of territorial ecosystems, sustainably manage forests, combat desertification, and halt and reverse land degradation and halt biodiversity loss

- Goal 17: Strengthen the means or implementation and revitalize the global partnership for sustainable development

According to Malaysia's Voluntary National Review of the Sustainable Growth Goals for 2017, our country has achieved tremendous strides in economic development, particularly in rural regions, alleviating poverty. As our former Prime Minister, Dato' Seri Najib Tun Razak, promised, "Malaysia is fully committed to the Post 2015 agenda - the Sustainable Development Goals and our goal to transform the world by 2030." As a result, the Economic Planning Unit established the Malaysian SDG Roadmap to include the 2030 Agenda into the Eleventh Malaysia Plan. The 11th Malaysia Plan (MP) theme is "anchoring grown on people," which aligns with the Sustainable Development Goals (SDG) concept of "leaving no one behind." Three objectives were established for the theme:

- Objective 1: People are the bedrock of the nation

- Objective 2: Preparing people for the future

- Objective 3: Everyone enjoys growth and development

In addition, the SDG roadmap Malaysia were divided into 3 phase which are (Nazry, 2021):

- Phase I (2016-2020) - prioritising SDG according to $11 \mathrm{MP}$

- Phase II (2020-2025) - focus on post 2020 goals and targets

- Phase III (2025-2030) - remaining goals and targets in line with Malaysia's capacity and global role

Malaysia funding for SDG programs and projects are focused on 9 priority goals which are listed below;

- Goal 3: Good health and well being

- Goal 4: Quality education

- Goal 7: Affordable and clean energy

- Goal 8: Decent work and economic growth

- Goal 9: Industry innovation and infrastructure

- Goal 11: Sustainable cities and communities

- Goal 14: Life below water

- Goal 15: Life on land

- Goal 16: Peace, justice and strong 
For the first phase of implementation (2016-2020), most SDG objectives were included in Malaysia's 11th Malaysia Plan, and Malaysia remains committed to addressing the remaining targets through the next Malaysia Plan (Nazry, 2021). Although Malaysia has matched the 11th Malaysia Plan with the SDGs and made significant progress toward each of the objectives, several remain dormant. According to the 2018 SDG Index and Dashboard report, the following SDGs remained stagnant: zero hunger (SDG 2), sustainable cities and communities (SDG 11), life on land (SDG 15), and partnership for the goals (SDG 17).

\section{Methodology}

\subsection{Target Community and Participants}

Greater Kuala Lumpur encompasses the Kuala Lumpur city and some sections of the Selangor Darul Ehsan state. It is a metropolitan area that is densely populated by Malaysian residents, industries, and commerce. The study examined selected secondary schools with pupils ranging from Form 1 to Form 5. (13 to 17 years old). Five high schools were identified in this area, including two cluster schools, two daily high schools, and one high-performance school (Table 1). These schools were chosen for their partnership with Universiti Malaya (Kelab Sahabat) and their willingness to engage in this study. All schools participating in the study have ethically consented and have already taken steps toward establishing a sustainable practice in their schools. 500 questionnaires were delivered to randomly selected respondents. The return rate of respondents was calculated to be 84.2 percent, based on 421 questionnaires collected from students.

Table 1. Selected high schools in Greater Kuala Lumpur as the target community

\begin{tabular}{llll}
\hline No. & School & High School Type & Location Coordinate \\
\hline 1 & SMK Damansara Damai 1 & Daily & $3^{\circ} 11^{\prime} 29.796^{\prime \prime} \mathrm{N} 101^{\circ} 35^{\prime} 32.532^{\prime \prime} \mathrm{E}$ \\
2 & SMK Seksyen-10 Kota Damansara & Daily & $3^{\circ} 10^{\prime} 9.84^{\prime \prime} \mathrm{N} 101^{\circ} 34^{\prime} 47.316^{\prime \prime} \mathrm{E}$ \\
3 & SMK Damansara-Utama & Cluster & $3^{\circ} 8^{\prime} 13.632^{\prime \prime} \mathrm{N} 101^{\circ} 37^{\prime} 31.512^{\prime \prime} \mathrm{E}$ \\
4 & SMJK Katholik & Cluster & $3^{\circ} 6^{\prime} 27.18^{\prime \prime} \mathrm{N} 101^{\circ} 39^{\prime} 7.308^{\prime \prime} \mathrm{E}$ \\
5 & SMK (P) Sri Aman & High Performance & $3^{\circ} 6^{\prime} 7.776^{\prime \prime} \mathrm{N} 101^{\circ} 37^{\prime} 41.556^{\prime \prime} \mathrm{E}$
\end{tabular}

\subsection{Research instrument}

The research was conducted utilizing a questionnaire to collect data, and it incorporates all 17 SDGs. It consists of 51 closed-ended questions that span a range of current social, economic, and environmental topics. Figure 1 depicts several key SDGs actions occurring in schools. Although these questions confine students' responses to the challenges, they will aid them in gaining insight into the SDGs (Stoet, 2017). Additionally, it assists pupils in responding appropriately to questions. The questionnaire included 3 parts: knowledge (16 Yes or No questions), attitude (17 statements), and practice (18 statements), as adapted from Jamaludin et al. (2020). The questions for each section are coded as stated below:

\section{Part A: Students' Background}

- Q1: Gender

- Q2: Age

- Q3: Race

- Q4: Schools' name

- Q5: Schools' location 
- Q6: Type of school

- Q7: Form

- Q8: Academic streaming

- Q9: Are you involved in environmental association club?

\section{Part B: Knowledge}

- K1 Women and man were not given the same opportunity in workforce.

- K2 Climate change affects agriculture.

- K3 Use of plastics pollute the sea

- K4 Straw and plastic bottles can be substituted to other substances

- K5 Poor citizens are being left behind.

- K6 Financial aid for the poor citizens is not enough.

- $\quad$ K7 Water is important for all living.

- K8 Waste separation is important to reduce the use of original resources.

- K9 Cooperation from various organization is important to preserve biodiversity.

- K10 Formal education is important for children from all over the world.

- K11 Number of HIV and AIDS diseases cases reduced.

- K12 Clean water sources are still inaccessible for some of the world citizen.

- K13 Forest areas in Malaysia must be protected to ensure the habitat of animals and act a carbon storage.

- K14 Job opportunity depends on the condition of the country's economy.

- K15 Relationship with various countries is important to preserve peace.

- K16 Farming activity depends on surrounding weather.

\section{Part C: Attitude}

- A1 I believe that women and men must be given the same opportunity in workforce.

- A2 In my opinion, climate change affects agriculture.

- A3 I supported the banning of the use of straw to save turtles.

- A4 I am ready to use aluminum bottles to bring to school.

- A5 I pitied those poor people who were left behind.

- A6 I am ready to donate to help poor people.

- A7 I feel that clean water is very important for daily use.

- A8 I support waste separation activity especially separating plastics.

- A9 In my opinion, the politicians have to focus on the sustainable needs of the community. 
- A10 I am happy to come to school and learn.

- A11 I believe that citizens that are free from HIV and AIDS diseases can help in developing a better future.

- A12 I want the individual who pollutes the river to be fine.

- A13 I feel that forest is a peaceful place and important for humans and animals.

- A14 Online shop reduces the need for a space to be developed.

- A15 I believe that peace can be achieved by protecting the relationship between countries.

- A16 Future of foods depends on current weather.

- A17 Online shopping helps reduce carbon footprint.

\section{Part D: Practice}

- P1 I work hard in a field if I like it.

- P2 I actively plant trees because I want a cooler environment.

- P3 I did not use plastic straw.

- P4 I eat at fast food restaurants less often.

- P5 I and my family give used clothes to the needy.

- P6 I used boxes or used items to create something.

- P7 I collected rainwater for outdoor used.

- P8 I separate my waste like plastics, paper, tin and food waste.

- P9 I watch television less often.

- P10 I dreamed of being a leader to the community.

- P11 I involved with selling activity.

- P12 I pick up rubbish in front of me.

- P13 I would rather walk or cycle to school if I did not live too far.

- P14 I help people with disabilities.

- P15 I respect my friends with different religion.

- P16 I only buy things that I need.

- P17 I used social media to spread awareness of the environment.

- P18 I buy things online. 


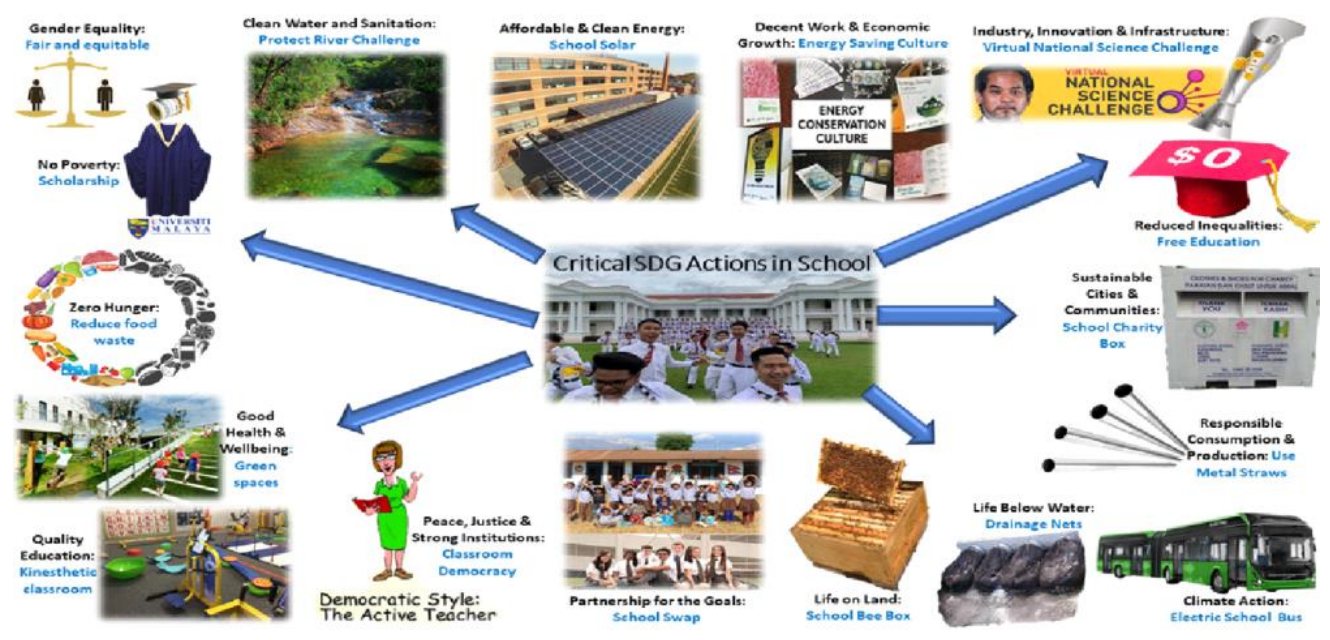

Figure 1. Critical SDGs actions in schools

\subsection{Scoring, Coding, and Statistical Analysis}

The test included 3 parts: knowledge, attitude, and practice. The first part, knowledge, has 16 items that evaluate SDG knowledge and are scored as "Yes" or "No". The second part is attitude, which includes 17 questions rated on a Likert scale of 5-points. As commonly utilized, the scale of 1 represents strong disagreement, 2 for normal disagreement, 3 for neutrality, 4 for normal agreement, and 5 for strong agreement. The last part, Practice, has 18 assertions which is also Likert 5-point rated, with 1 representing never, 2 depicting seldom, while 3, 4 and 5 represent once, twice, and often, respectively.

The collection of data was then analyzed using SPSS (version 20). SPSS employed a descriptive, frequency, and correlation analysis. The mode of Spearman Rho correlation was utilized to examine the association amongst the variables of knowledge, attitude, and practice. On the other hand, the test Kruskal-Wallis was utilized to determine the significance of differences between groups. The questionnaire was subjected to a reliability test, and its reliability was certified using the Cronbach Alpha coefficient (Table 2). According to the reliability test, all variables indicating knowledge, attitude, and behavior related to SDGs have a high level of internal consistency, with a Cronbach Alpha coefficient of 0.814 . Table 3 illustrates the coding used to reflect each statement from the knowledge, attitude, and practice domains.

Table 2. Cronbach coefficient alpha for reliability level determination

\begin{tabular}{cc}
\hline Cronbach alpha (a) coefficient & Reliability \\
\hline$<0.65$ & Not acceptable \\
\hline $0.65-0.95$ & Acceptable \\
\hline$>0.95$ & Redundant \\
\hline
\end{tabular}

\section{Results and Discussions}

\subsection{Demographic profile of respondents}

From the 8575 total population in the selected schools, 421 responses were acquired. The quantity of feedbacks was calculated using a $95 \%$ threshold of significance and a $5 \%$ margin of error. The precise aim for a minimum sample size of 381 respondents is 381 respondents. 
Figure 2 illustrates the percentage of respondents who belong to various demographic groups based on their gender, school type, academic stream, student maturity (as measured by form), and environmental club. The majority of respondents (65.3 percent) were female, while 34.7 percent were male. Respondents were selected at random from five schools and divided into three types: daily, cluster, and high-performance. Figure 2 (iii) shows how respondents' background studies were categorised based on their academic level (form). The biggest percentage of responders (31.6\%) comes from Form 2, while the lowest percentage $(10.7 \%)$ comes from Form 3 . The majority of respondents are from Forms 1,2 , and 3 , and do not belong to any academic stream. There is a little percentage discrepancy between answers from the science and art steams. Finally, only 12.8 percent of respondents were members of an environmental club, whereas the majority were not.

Table 3. Coding for knowledge (K), attitude (A) and practice (P)
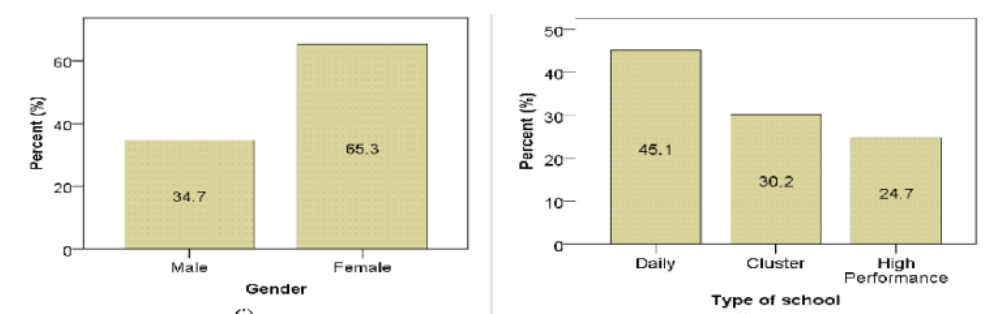

(ii)

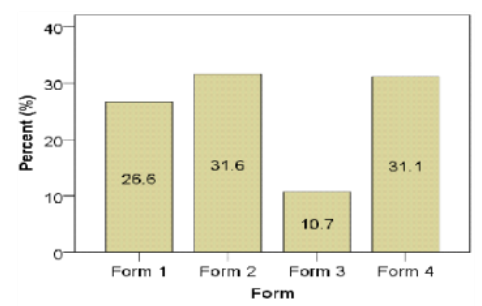

(iii)
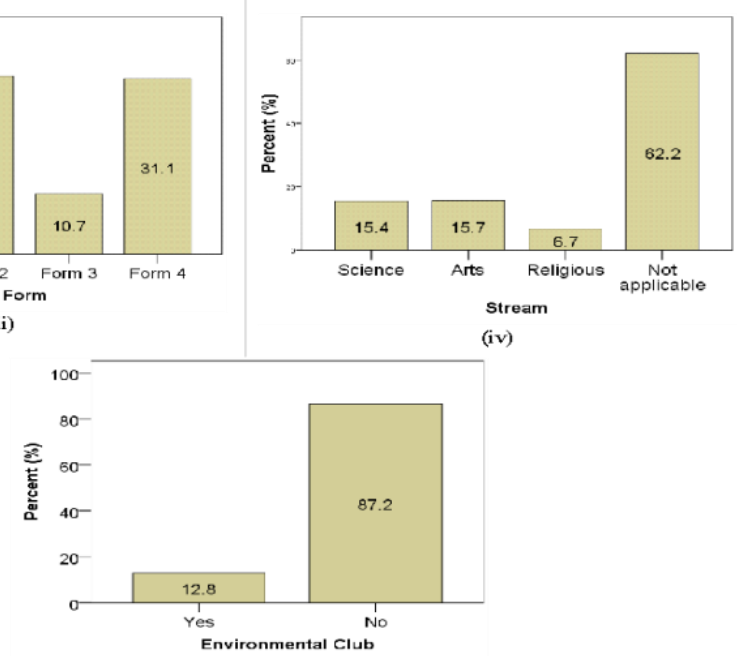

(iv)

Figure 2. Respondents' demographic profile i) Gender ii) High school type iii) Form (iv)

Academic streaming (v) Environmental club participation

\subsection{Youth Awareness Level}

As shown in Table 4, the greatest percentages of respondents agreed with the statement "women and men did not have equal chances in the workforce," while a larger percentage of respondents disagreed with the statement "number of HIV and AIDS illness cases reduced." This finding shows that the vast majority of respondents had a firm grasp of the Sustainable Development Goals. The highest proportion of respondents who responded 'Yes' to the statement 'water is essential for all life' was 98.6 percent, showing that respondents are worried about water quality. 
Table 4. Respondents' awareness of the SDGs in knowledge section

\begin{tabular}{|c|c|c|c|c|c|c|c|c|c|c|}
\hline \multicolumn{2}{|r|}{ Goal } & \multicolumn{2}{|c|}{ Knowledge (K) } & \multicolumn{4}{|c|}{ Attitude (A) } & \multicolumn{3}{|c|}{ Practice (P) } \\
\hline 1 & No Poverty & 5 & 6 & 5 & & 6 & & 5 & & \\
\hline 2 & Zero Hunger & 2 & 16 & 2 & & 16 & & & & \\
\hline 3 & Good health and well being & 11 & & 11 & & & & 4 & 13 & \\
\hline 4 & Quality education & 10 & & 10 & & & & & & \\
\hline 5 & Gender equality & 1 & & 1 & & & & & & \\
\hline 6 & Clean water and sanitation & 7 & 12 & 7 & & & & 7 & & \\
\hline 7 & Affordable and clean energy & & & 17 & & & & 8 & 9 & 13 \\
\hline 8 & Decent work and economic growth & 14 & & 17 & & & & 11 & 18 & \\
\hline 9 & Sustainable infrastructure & 4 & & 12 & 14 & 17 & & 6 & 11 & 18 \\
\hline 10 & Reduced inequalities & 5 & & 5 & & & & 14 & 15 & \\
\hline 11 & Sustainable cities and communities & 8 & & 14 & & & & 12 & 13 & 18 \\
\hline 12 & $\begin{array}{l}\text { Responsible consumption and } \\
\text { production }\end{array}$ & 4 & & 3 & 4 & 8 & 12 & 3 & 8 & 16 \\
\hline 13 & Climate action & 2 & 16 & 2 & 16 & 17 & & 2 & & \\
\hline 14 & Life below water & 3 & 9 & 3 & 12 & & & 12 & & \\
\hline 15 & Life on land & 9 & 13 & 13 & 14 & & & 2 & 12 & \\
\hline 16 & Reliable institutions & 15 & & 9 & 12 & 15 & & 10 & 15 & \\
\hline 17 & Partnerships for the goals & 9 & & 15 & & & & 10 & & \\
\hline
\end{tabular}

\begin{tabular}{|c|c|c|c|}
\hline \multicolumn{2}{|r|}{ Knowledge (K) } & \multicolumn{2}{|c|}{$\begin{array}{l}\text { Likert scale percentage } \\
\qquad(\%)\end{array}$} \\
\hline & & \multirow{2}{*}{$\begin{array}{c}\text { Yes (1) } \\
43.7\end{array}$} & \multirow{2}{*}{$\begin{array}{l}\text { No (2) } \\
56.3\end{array}$} \\
\hline 1 & Women and men did not have equal opportunities in the workforce. & & \\
\hline 2 & Agriculture is impacted by climate change. & 95.7 & 4.3 \\
\hline 3 & Plastic pollution in the sea is a result of the use of plastics. & 94.3 & 5.7 \\
\hline 4 & Straw and plastic bottles may be replaced with alternative materials. & 87.9 & 12.1 \\
\hline 5 & The poor people are being left behind. & 64.8 & 35.2 \\
\hline 6 & Financial assistance to poor people is insufficient. & 77.4 & 22.6 \\
\hline 7 & Water is necessary for all life. & 98.6 & 1.4 \\
\hline 8 & Waste separation is critical for conserving natural resources. & 92.9 & 7.1 \\
\hline 9 & Collaboration between diverse organizations is critical for biodiversity conservation. & 94.3 & 5.7 \\
\hline 10 & Formal education is critical for children everywhere. & 93.3 & 6.7 \\
\hline 11 & The number of HIV and AIDS cases has decreased. & 41.3 & 58.7 \\
\hline 12 & For some global citizens, clean water sources remain unavailable. & 91.9 & 8.1 \\
\hline 13 & $\begin{array}{l}\text { Malaysia's forest lands must be preserved to provide animal habitat and function as a } \\
\text { carbon sink. }\end{array}$ & 95.5 & 4.5 \\
\hline 14 & Job opportunities are contingent upon the state of the country's economy. & 79.3 & 20.7 \\
\hline 15 & Relationships with different nations are critical for maintaining peace. & 97.1 & 2.9 \\
\hline 16 & Agriculture is weather-dependent. & 94.5 & 5.5 \\
\hline
\end{tabular}


The Likert scale with 5 points measures respondents' agreement with a statement about their attitude toward sustainability (Table 5). Scale 1 indicates significant disagreement, whereas scale 5 indicates great agreement. By and large, respondents have a favorable attitude toward sustainable living, as seen by the high proportion on the fifth scale. This indicates that respondents at the chosen schools have a favorable attitude toward sustainable development.

In previous research by Afroz and Ilham (2020), they reported a high level of awareness towards SDGs among university students, shown by a significant number of students who possess high knowledge with a positive attitude. Their study involved 382 students from a prominent university in Kuala Lumpur, Malaysia. However, their level of SDGs practice is low. It revealed a minor negative association between student knowledge and practice, indicating that while university students have a high level of knowledge about the SDGs, their practice level is slightly lower. According to the researchers, this can be increased through strategic approaches and intervention programs by the university. Nonetheless, there is a strong positive connection between student attitude and practice proficiency. This showed that by having a positive attitude, students would be more driven towards practicing actions aligned withSDGs. It should be noted that environmental approaches vary between institutions, and thus students may have different levels of awareness towards SDGs.

According to another study conducted by Jamaludin et al. (2020), the majority of students had a favorable attitude toward SDGs activities. Regrettably, more focus and attention should be given to students from non-science educational streams and those from the lower socioeconomic income categories in order to help them better understand the SDGs.

Table 5. The attitude of respondents towards SDGs

\begin{tabular}{|c|c|c|c|c|c|c|}
\hline \multirow{2}{*}{\multicolumn{2}{|c|}{ Attitude (A) }} & \multicolumn{5}{|c|}{ Likert scale percentage (\%) } \\
\hline & & \multirow{2}{*}{$\begin{array}{c}1 \\
2.9\end{array}$} & \multirow{2}{*}{$\begin{array}{c}2 \\
4.0\end{array}$} & \multirow{2}{*}{$\begin{array}{c}3 \\
13.1\end{array}$} & \multirow{2}{*}{$\begin{array}{c}4 \\
26.8\end{array}$} & \multirow{2}{*}{$\begin{array}{c}5 \\
53.2\end{array}$} \\
\hline 1 & $\begin{array}{l}\text { I think that women and men should have equal access to the } \\
\text { workforce. }\end{array}$ & & & & & \\
\hline 2 & Climate change, in my view, has an effect on agriculture. & 1.0 & 3.6 & 12.1 & 39.4 & 43.9 \\
\hline 3 & $\begin{array}{l}\text { I voted in favor of prohibiting the use of straw in order to } \\
\text { preserve turtles. }\end{array}$ & 5.5 & 5.5 & 13.1 & 20.0 & 56.1 \\
\hline 4 & I am prepared to carry an aluminium bottle to school. & 11.2 & 10.9 & 34.6 & 20.9 & 22.3 \\
\hline 5 & I felt pity for those who had been abandoned. & 1.9 & 2.4 & 11.2 & 25.7 & 58.9 \\
\hline 6 & I am willing to make a donation to assist the needy. & 1.9 & 0.7 & 13.1 & 29.9 & 54.4 \\
\hline 7 & $\begin{array}{l}\text { I believe that safe drinking water is essential for everyday } \\
\text { usage. }\end{array}$ & 1.7 & 1.7 & 2.9 & 10.2 & 83.6 \\
\hline 8 & $\begin{array}{l}\text { I favour trash separation activities, particularly those that } \\
\text { separate plastics. }\end{array}$ & 2.6 & 2.6 & 12.4 & 30.4 & 52.0 \\
\hline 9 & $\begin{array}{l}\text { Politicians, in my view, must prioritise the community's long- } \\
\text { term requirements. }\end{array}$ & 1.7 & 3.6 & 17.3 & 27.6 & 49.9 \\
\hline 10 & I'm delighted to attend school and study. & 3.8 & 3.1 & 29.7 & 27.3 & 36.1 \\
\hline 11 & $\begin{array}{l}\text { I think that people who are HIV- and AIDS-free may } \\
\text { contribute to the development of a brighter future. }\end{array}$ & 3.3 & 4.5 & 18.8 & 26.1 & 47.2 \\
\hline 12 & $\begin{array}{l}\text { I want the person responsible for polluting the river to be } \\
\text { punished. }\end{array}$ & 4.3 & 2.9 & 8.8 & 22.3 & 61.7 \\
\hline 13 & $\begin{array}{l}\text { I believe that forests are a tranquil area that is necessary for } \\
\text { humans and animals. }\end{array}$ & 1.9 & 3.6 & 9.0 & 25.4 & 60.1 \\
\hline 14 & $\begin{array}{l}\text { Online stores eliminate the requirement for a physical } \\
\text { location to be established. }\end{array}$ & 2.4 & 5.5 & 30.2 & 29.2 & 32.8 \\
\hline 15 & $\begin{array}{l}\text { I think that peace may be achieved through safeguarding } \\
\text { bilateral ties. }\end{array}$ & 1.0 & 2.4 & 8.3 & 28.5 & 59.8 \\
\hline
\end{tabular}




\begin{tabular}{|c|c|c|c|c|c|c|}
\hline \multirow{2}{*}{\multicolumn{2}{|c|}{ Attitude (A) }} & \multicolumn{5}{|c|}{ Likert scale percentage (\%) } \\
\hline & & \multirow{2}{*}{$\begin{array}{c}1 \\
4.5\end{array}$} & \multirow{2}{*}{$\begin{array}{c}2 \\
8.1\end{array}$} & \multirow{2}{*}{$\begin{array}{c}3 \\
29.9\end{array}$} & \multirow{2}{*}{$\begin{array}{c}4 \\
30.2\end{array}$} & \multirow{2}{*}{$\begin{array}{c}5 \\
27.3\end{array}$} \\
\hline 16 & The future of foods is conditional on the present weather. & & & & & \\
\hline 17 & $\begin{array}{l}\text { Online purchasing contributes to the reduction of carbon } \\
\text { emissions. }\end{array}$ & 2.6 & 7.6 & 40.9 & 25.7 & 23.3 \\
\hline
\end{tabular}

1 - Strongly disagree, 2 - Disagree, 3 - Neutral, 4 - Agree, 5 - Strongly agree

For practice, scale 1 means 'Never' and scale 5 means 'Always'. Table 6 shows how practice distribution varies by size in respect to SDGs. On scale 5, the most frequent claims are 5 . It showed that respondents always work hard in a profession they love, give clothes to the poor, prefer to walk or bike to school if they live nearby, value friends of various faiths, and buy just what they really need. Overall, respondents' dedication to sustainable development remains low. Overall, respondents' attitudes toward sustainable development are comparable to those of university students in Malaysia (Afroz \& Ilham, 2020).

Table 6. Respondents' practice towards SDGs

\begin{tabular}{|c|c|c|c|c|c|c|}
\hline \multicolumn{2}{|r|}{ Practice (P) } & \multicolumn{5}{|c|}{ Likert scale percentage (\%) } \\
\hline & & 1 & 2 & 3 & 4 & 5 \\
\hline 1 & If I like a field, I work diligently in it. & 3.8 & 10.0 & 7.4 & 27.6 & 51.3 \\
\hline 2 & $\begin{array}{l}\text { I'm aggressively reforesting in order to create a } \\
\text { cooler atmosphere. }\end{array}$ & 20.2 & 26.6 & 27.6 & 16.4 & 9.3 \\
\hline 3 & I did not use a straw made of plastic. & 13.1 & 37.3 & 16.2 & 21.4 & 12.1 \\
\hline 4 & I dine out less often at fast food restaurants. & 8.3 & 36.3 & 13.1 & 25.4 & 16.8 \\
\hline 5 & $\begin{array}{l}\text { My family and I donate gently worn clothing to } \\
\text { the less fortunate. }\end{array}$ & 8.8 & 16.6 & 15.0 & 26.4 & 33.3 \\
\hline 6 & $\begin{array}{l}\text { I created something using boxes or found } \\
\text { objects. }\end{array}$ & 12.6 & 24.0 & 20.0 & 26.8 & 16.6 \\
\hline 7 & I gathered rainwater for use in the garden. & 39.0 & 18.8 & 18.0 & 12.4 & 11.9 \\
\hline 8 & $\begin{array}{l}\text { I sort my trash into categories such as plastics, } \\
\text { paper, tin, and food waste. }\end{array}$ & 19.2 & 26.6 & 14.3 & 20.9 & 19.0 \\
\hline 9 & I watch less television. & 18.3 & 29.0 & 11.6 & 17.3 & 23.8 \\
\hline 10 & I aspired to be a community leader. & 35.6 & 13.1 & 17.8 & 16.6 & 16.9 \\
\hline 11 & I'm engaged in the selling process. & 24.7 & 16.4 & 24.7 & 20.2 & 14.0 \\
\hline 12 & I clean up the area in front of me. & 4.0 & 28.3 & 11.1 & 30.4 & 26.1 \\
\hline 13 & $\begin{array}{l}\text { I'd like to walk or bike to school provided it } \\
\text { wasn't too far. }\end{array}$ & 11.4 & 12.4 & 7.6 & 20.9 & 47.7 \\
\hline 14 & I assist those with impairments. & 6.4 & 18.1 & 20.9 & 27.5 & 27.1 \\
\hline 15 & I respect my friends who practice other religions. & 1.2 & 5.2 & 7.1 & 15.4 & 71.0 \\
\hline 16 & I purchase just what I need. & 4.8 & 20.9 & 12.8 & 30.6 & 30.6 \\
\hline
\end{tabular}




\begin{tabular}{|c|l|c|c|c|c|c|}
\hline \multicolumn{2}{|c|}{ Practice (P) } & \multicolumn{4}{c|}{ Likert scale percentage (\%) } \\
\cline { 3 - 6 } & \multicolumn{1}{|l|}{1} & 2 & 3 & 4 & 5 \\
\hline 17 & $\begin{array}{l}\text { I utilized social media to raise environmental } \\
\text { awareness. }\end{array}$ & 27.1 & 24.9 & 20.9 & 14.0 & 13.1 \\
\hline 18 & I make purchases online. & 20.0 & 22.6 & 16.6 & 18.8 & 22.1 \\
\hline
\end{tabular}

1 - Strongly disagree, 2 - Disagree, 3 - Neutral, 4 - Agree, 5 - Strongly agree

Additional statistical analysis using Spearman Rho correlation data in Table 7 demonstrates a significant and robust association between practice and attitude $(r=0.435$, with a significance level of p0.01). Apparently, a minimal correlation exists between knowledge, attitude, and practice. The inverse relationship between knowledge, attitude, and practice shows that the students' level of knowledge had no impact on their attitudes and behaviors toward sustainability. (Zulkifli et al., 2018).

Table 7. Knowledge, attitude and practice on SDGs correlation

\begin{tabular}{|c|c|c|c|c|c|}
\hline & & & Knowledge (K) & Attitude (A) & Practice $(\mathrm{P})$ \\
\hline \multirow[t]{9}{*}{$\begin{array}{l}\text { Spearman's } \\
\text { Rho }\end{array}$} & \multirow[t]{3}{*}{ Attitude (A) } & $\begin{array}{l}\text { Coefficient of } \\
\text { Correlation }\end{array}$ & $-.331^{* *}$ & 1.000 & $.435^{* *}$ \\
\hline & & Sig. (2-tailed) & .000 & .000 & .000 \\
\hline & & N (Respondents) & 421 & 421 & 421 \\
\hline & \multirow[t]{3}{*}{ Practice $(\mathrm{P})$} & $\begin{array}{l}\text { Coefficient of } \\
\text { Correlation }\end{array}$ & $-.267^{* *}$ & $.435^{* *}$ & 1.000 \\
\hline & & Sig. (2-tailed) & .000 & .000 & .000 \\
\hline & & N (Respondents) & 421 & 421 & 421 \\
\hline & \multirow[t]{3}{*}{ Knowledge (K) } & $\begin{array}{l}\text { Coefficient of } \\
\text { Correlation }\end{array}$ & 1.000 & $-.331^{* *}$ & $-.267^{* *}$ \\
\hline & & Sig. (2-tailed) & .000 & .000 & .000 \\
\hline & & N (Respondents) & 421 & 421 & 421 \\
\hline
\end{tabular}

In statistical analysis, $\left({ }^{* *}\right)$ is the sign that represents that the results are statistically significant. Negative values showed that the data is negatively correlated with each other.

\subsection{Theoretical Implications}

This study adds theoretically to the body of research on the connection between students' knowledge, attitude, and practice (KAP) of the Sustainable Development Goals (SDGs). The findings indicated that all variables had a favorable direct effect on contributing to the achievement of the SDGs. Even though the hypotheses produced were not completely reliant on the theory's model, the results may implicitly contribute to the existing literature on KAP theory. This aligns with Isa (2017), who utilized KAP theory rather than the Theory of Planned Behavior (TPB) to assess sustainable campus awareness. The findings supported the KAP theory by demonstrating that students' knowledge shapes their attitudes, which in turn results in planned behaviors that support SDGs.

Commitment on behalf of the students is critical to establishing a positive practice. This is critical since it has been demonstrated that when individuals lack dedication to a cause, they prefer to overlook the negative consequences of their actions (Liu \& Lin, 2015). Additionally, it is critical to examine the relationship between knowledge, attitude, and practice related to achieving the SDGs. This will help to 
emphasize the critical role of knowledge in fostering an attitude that promotes individuals' activities that contribute to environmental sustainability (Chen \& Tsai, 2016). This study demonstrates that persons with a greater degree of knowledge are more likely to exhibit a sustainable attitude and engage in SDG-related activities. As a result, once individuals get a high level of understanding, they will demonstrate a strong attitude and practice toward achieving the SDGs.

This research adds to the existing SDG literature by focusing on high school pupils in Greater Kuala Lumpur, Malaysia. The intensification of awareness and education in support of the SDGs has sparked renewed interest in recent years, particularly in pro-environmental practices (Yusliza et al., 2020). This study concentrated on high school students because they are the primary group that will establish and adopt a long-term sustainable lifestyle. Additionally, it is worthwhile to improve students' awareness of the actions that responsible students must take to ensure sustainability. Zamora-Polo et al. (2019), in their study in Spain, also found that in order to inculcate the knowledge about SDGs, special training is needed, and the information must be embedded in the education curriculum as part of the Education for Sustainable Development (ESD) approach.

On the other hand, this study made significant practical contributions. Although this study was conducted at secondary schools in a Greater Kuala Lumpur urban region, it may have significant implications for educational institutions nationwide, including schools, training institutions, and universities. The rationale is based on the idea that educational institutions can accomplish the SDGs by providing students with relevant information, skills, and experiences (Yusliza et al., 2020).

As a consequence, educational institutions must offer emotional rather than cognitive sustainability-focused topics and activities to all learners. This research also helped senior management realize the need for appropriate and ongoing evaluation mechanisms to evaluate and monitor students' effects on sustainability activities required to achieve the SDGs. Another important feature of this research is that it may help governments and commercial groups create sustainable plans and strategies for business operations.

\subsection{Practical Implications in Sustainable Campus Planning}

Cortese (2003) suggested a sustainable campus model called 'Higher Education Modelling Sustainability as a Fully Integrated System.' The concept emphasizes that higher education institutions should act as mentors and give knowledge and information to students and the surrounding community to help achieve sustainability. According to Cortese (2003), a campus's sustainability requires integration and collaboration between teaching, research, operations, and the campus community's ties with the surrounding community. This includes everyday campus operations, including building operations that promote soft landscaping, energy-efficient building systems, and efficient use of water and other resources.

The development of a sustainable campus should include both the physical and environmental aspects of the campus, such as traffic, land use, and infrastructure (Burton, 2000), and the socioeconomic aspects such as curriculum, research, and scholarships (Libunao \& Peter, 2013). Many campuses now approach sustainability concerns in silos. According to McMillin and Dyball (2009), sustainable education is typically separated from sustainable research. Similarly, campus sustainability programmes and operations frequently have their own goals and techniques without integrating with other components (McMillin \& Dyball, 2009). McMillin \& Dyball (2009) developed a sustainable campus concept based on complete sustainability principles. They emphasized that this strategy maximizes universities' role as change agents for sustainability. Students should be active in sustainability research and operations on campus and in specific academic disciplines.

The movement towards a sustainable campus was inspired by the 1990 Talloires Declaration, adopted during an international meeting in Talloires, France. A multidisciplinary approach was stressed for the creation of a sustainable campus. In order to assist sustainable development, academics, university administrators, and industry environmental practitioners must collaborate to establish curriculum, research projects, operations, service activities, and community, national, and worldwide outreach. A sustainable campus should also improve partnerships with elementary and secondary school administrations to foster interdisciplinary teaching about population, environment, and sustainable development. A sustainable campus should be able to reach out nationally and internationally. 
Collaboration with external groups is critical to promoting global university initiatives toward a sustainable future (Isa, 2017).

\section{Conclusions}

There has been a rise in global interest towards SDGs recently. The present study adds to the increasing body of information on sustainability planning. This study's goal was to see whether students' involvement in SDG activities correlated with their knowledge and attitudes about the goals. It is justified by prior research on the link of knowledge, attitude, and practice to the SDGs. Our results show that students are aware of the SDGs' elements, have a positive perception about them, and implement them often. Overall, the degree of awareness is adequate. There was no link between knowledge, attitude, and practice. We found a small but significant relationship between attitude and practice $(r=0.43)$. Surprisingly, students showed high levels of sustainability knowledge and comprehension and a significant willingness to engage in SDG activities. Students are more aware of and attentive to sustainability-related activities due to their personal knowledge or the high schools' comprehensive approach to curriculum and direction. School type $[r=-0.239]$ and academic stream $[r=-0.209]$ showed weak and negative correlations with knowledge, whereas student maturity had a substantial but negative connection with knowledge [ $r=-0.300]$. It is suggested that students get familiar with SDGs in order to encourage them to practice their new knowledge. Additionally, students need to be exposed to more global goals-related activities, and the SDGs must also be incorporated into non-science subjects in a comprehensive curricular of Education for Sustainable Development (ESD).

\section{Acknowledgements}

The authors acknowledge Universiti Malaya and UMCares (RU009-2017X,RU013-2017AG) for providing the opportunity and support to conduct the research.

\section{References}

Afroz, N., \& Ilham, Z. (2020). Assessment of knowledge, attitude and practice of university students towards sustainable development goals (SDGs). The Journal of Indonesia Sustainable Development Planning, 1(1), 31-44. https://doi.org/10.46456/jisdep.v1i1.12

Altin, A., Tecer, S., Tecer, L., Altin, S., \& Kahraman, B. F. (2014). Environmental awareness level of secondary school students: A case study in Balıkesir (Türkiye). Procedia-Social and Behavioral Sciences, 141, 1208-1214. https://doi.org/10.1016/j.sbspro.2014.05.207

Aminrad, Z., Zakariya, S. Z. B. S., Hadi, A. S., \& Sakari, M. (2013). Relationship between awareness, knowledge and attitudes towards environmental education among secondary school students in Malaysia.

World Applied Sciences Journal, 1326-1333. https://doi.org/10.5829/idosi.wasj.2013.22.09.275.

Ang, S. M. (2021). Awareness on sustainable development goals among university students in Malaysia. Asian Journal of Research in Education and Social Sciences, 3(1), 105-116.

Berglund, T., Gericke, N., \& Chang Rundgren, S. N. (2014). The implementation of education for sustainable development in Sweden: Investigating the sustainability consciousness among upper secondary students. Research in Science \& Technological Education, 32(3), 318-339. https://doi.org/10.1080/02635143.2014.944493

Borges, J. C., Cezarino, L. O., Ferreira, T. C., Sala, O. T. M., Unglaub, D. L., \& Caldana, A. C. F. (2017). Student organizations and communities of practice: Actions for the 2030 agenda for sustainable development. The International Journal of Management Education, 15(2), 172-182. https://doi.org/10.1016/J.IJME.2017.02.011

Burton, E. (2000). The compact city: Just or just compact? A preliminary analysis. Urban Studies, 37(11), 1969-2006. https://doi.org/10.1080\%2F00420980050162184

Carant, J. B. (2017). Unheard voices: A critical discourse analysis of the Millennium Development Goals' evolution into the Sustainable Development Goals. Third World Quarterly, 38(1), 16-41. https://doi.org/10.1080/01436597.2016.1166944 
Chen, C. L., \& Tsai, C. H. (2016). Marine environmental awareness among university students in Taiwan: A potential signal for sustainability of the oceans. Environmental Education Research, 22(7), 958977. https://doi.org/10.1080/13504622.2015.1054266

Cortese, A. D. (2003). The critical role of higher education in creating a sustainable future. Planning for Higher Education, 31(3), 15-22.

Hamid, Z. A. (2013). The dangerous, careless folly of biodiversity loss. Agriculture and Food Security, 2(1), 1-3. https://doi.org/10.1186/2048-7010-2-16

Ideland, M., \& Malmberg, C. (2014). 'Our common world' belongs to 'Us': Constructions of otherness in education for sustainable development. Critical Studies in Education, 55(3), 369-386. https://doi.org/10.1080/17508487.2014.936890

Isa, N. K. M. (2017). Sustainable campus and academic staffs awareness and behaviour in Malaysia's institutions of higher learning: A case study of UPSI. Geografia-Malaysian Journal of Society and Space, 12(6), 89-99.

Jamaludin, A. A., Ilham, Z., Zulkifli, N. E. I., Wan-Mohtar, W. A. A. Q. I., Halim-Lim, S. A., Ohgaki, H., Ishihara, K., \& Akitsu, Y. (2020). Understanding perception and interpretation of Malaysian university students on renewable energy. AIMS Energy, 8(6), 1029-1044. https://doi.org/10.3934/energy.2020.6.1029

Kristensen, H. S., \& Mosgaard, M. A. (2020). A review of micro level indicators for a circular economymoving away from the three dimensions of sustainability? Journal of Cleaner Production, 243, 118531. https://doi.org/10.1016/jclepro.2019.118531

Lee, C., \& Chew-Ging, L. (2017). The evolution of development planning in Malaysia. Journal of Southeast Asian Economies, 34(3), 436-461. Libunao, W., \& Peter, C. (2013). Education for sustainable development practices among polytechnics in Malaysia [Conference session]. International Conference on Social Science Research (ICSSR), Penang, Malaysia.

Liu, S. C., \& Lin, H. S. (2015). Exploring undergraduate students' mental models of the environment: Are they related to environmental affect and behavior? The Journal of Environmental Education, 46(1), 23-40. https://doi.org/10.1080/00958964.2014.953021

McMillin, J., \& Dyball, R. (2009). Developing a whole-of-university approach to educating for sustainability: Linking curriculum, research and sustainable campus operations. Journal of Education for Sustainable Development, 3(1), 55-64. https://doi.org/10.1177\%2F097340820900300113

Nazry, K. (2021). A review of the sustainable development goals policy framework for Malaysian local governments. Malaysian Journal of Sustainable Environment, 8(2), 157-177. https://doi.org/10.24191/myse.v8i2.13245

Hassan, A., Noordin, T. A., \& Sulaiman, S. (2010). The status on the level of environmental awareness in the concept of sustainable development amongst secondary school students. Procedia-Social and Behavioral Sciences, 2(2), 1276-1280. https://doi.org/10.1016/j.sbspro.2010.03.187

Sachs, J. D. (2012). From millennium development goals to sustainable development goals. The Lancet, 379(9832), 2206-2211. https://doi.org/10.1016/S0140-6736(12)60685-0

Stoet, G. (2017). PsyToolkit: A novel web-based method for running online questionnaires and reactiontime experiments. Teaching of Psychology, 44(1), 24-31. https://doi.org/10.1177\%2F0098628316677643

Yap, J. B. H., Chua, C. Y., \& Skitmore, M. (2021). Towards sustainable mobility with Transit-Oriented Development (TOD): Understanding greater Kuala Lumpur. Planning Practice \& Research, 36(3), 314336. https://doi.org/10.1080/02697459.2021.1883249

Yusliza, M. Y., Amirudin, A., Rahadi, R. A., Athirah, N. A. N. S., Ramayah, T., Muhammad, Z., Mas, F. D., Massaro, M., Saputra, J., \& Mokhlis, S. (2020). An investigation of pro-environmental behaviour and sustainable development in Malaysia. Sustainability, 12(17), 7083. https://doi.org/10.3390/su12177083

Zamora-Polo, F., Sánchez-Martín, J., Corrales-Serrano, M., \& Espejo-Antúnez, L. (2019). What do university students know about sustainable development goals? A realistic approach to the reception of this UN program amongst the youth population. Sustainability, 11(13), 1-19. https://doi.org/10.3390/su11133533

Zulkifli, N. E. I., Jamaludin, A. A., Ilham, Z., Jani, R., \& Mokhtar, M. I. (2018). The Daily Practice of UM Students on Electricity Usage towards Energy Conservation. Climate Change and Campus Sustainability (5RCCS2018), 133. 